\title{
Household transmission of SARS-CoV-2; a prospective longitudinal study showing higher viral load and transmissibility of the Alpha variant compared to previous strains
}

\author{
Cathinka Halle Julin ${ }^{1, *}$, Anna Hayman Robertson ${ }^{1, *}$, Olav Hungnes ${ }^{1}$, Gro Tunheim ${ }^{1}$, Terese \\ Bekkevold $^{1}$, Ida Laake ${ }^{1}$, Idunn Forland Aune ${ }^{1}$, Rikard Rykkvin ${ }^{1}$, Dagny Haug Dorenberg ${ }^{1}$, \\ Kathrine Stene-Johansen', Einar Sverre Berg ${ }^{1}$, Johanna Eva Bodin ${ }^{1}$, Fredrik Oftung ${ }^{1}$, Anneke \\ Steens $^{1}$, Lisbeth Meyer Næss ${ }^{1, * * *}$ \\ *These authors contributed equally \\ ***Corresponding author \\ ${ }^{1}$ Division of Infection Control, Norwegian Institute of Public Health, P.O.Box 222 Skøyen, 0213 Oslo, \\ Norway
}

\section{SUMMARY}

\section{Objectives}

We studied the secondary attack rate (SAR), risk factors, and precautionary practices of household transmission in a prospective, longitudinal study. We further compared transmission between the Alpha (B.1.1.7) variant and non-Variant of Concern (non-VOC) viruses.

\section{Methods}

We recruited households of 70 confirmed COVID-19 cases with 146 household contacts from May 2020 to May 2021. Participants donated biological samples 8 times over 6 weeks and answered questionnaires. Whole genome sequencing and droplet digital PCR were used to establish the SARSCoV-2 variant and viral load.

\section{Results}

SARS-CoV-2 transmission occurred in $60 \%$ of the households, and the overall SAR for household contacts was $50 \%$. The SAR was significantly higher for the Alpha variant (78\%) compared with nonVOC viruses (43\%) and was associated with a higher viral load. SAR was higher in household contacts aged $\geq 40$ years (69\%) than in younger contacts (40-47\%), and for contacts of cases with loss of taste/smell. Children had lower viral loads and were more often asymptomatic than adults. Sleeping separately from the primary case reduced the risk of transmission.

\section{Conclusions}

We found substantial household transmission, particularly for the Alpha variant. Precautionary practices seem to reduce SAR, but preventing household transmission may become difficult with more contagious variants.

Key words: Household transmission; SARS-CoV-2; COVID-19; Alpha variant; B.1.1.7; Secondary Attack Rate; SAR; viral load, ddPCR

Running title: Household transmission of SARS-CoV-2 


\section{INTRODUCTION}

SARS-CoV-2, the virus that causes the respiratory disease COVID-19, was first detected in China in 2019 and spread rapidly throughout the world. In March 2020, the World Health Organization (WHO) declared COVID-19 a pandemic. Households have been one of the most important sites of transmission in Norway (1), as well as in other countries (2). It is therefore important to identify risk factors for household transmission and effective precautionary practices to contain the epidemic. Moreover, secondary attack rate (SAR) calculated from household studies provides an important measure of the transmissibility of SARS-CoV-2.

Previous household transmission studies have mainly described transmission of the SARS-CoV-2 variants dominating in the early phase of the pandemic or have not described the genetic variant(s). However, the Alpha variant/Variant of Concern (VOC) 202012/01 (Pango lineage B.1.1.7) rapidly outcompeted other SARS-CoV-2 lineages in the UK after its emergence in November $2020(3,4)$. The first confirmed case of the Alpha variant in Norway was reported in December 2020, and from midFebruary 2021 until July 2021 it was the dominant variant (1, 5). Even though increased transmissibility of the Alpha variant has been shown (6-8), knowledge is still sparse regarding how it affects the SAR in households.

We conducted a prospective longitudinal household study to investigate the SAR in Norwegian households, and to identify risk factors for transmission within these households, using frequent testing and biological sampling, together with questionnaire data. Close follow-up and systematic data collection allowed for determination of the role of viral load in transmission. We used the droplet digital PCR (ddPCR) technique to quantify SARS-CoV-2 viral RNA due to its greater accuracy and precision compared to traditional quantitative PCR (RT-qPCR) $(9,10)$. Moreover, we compared the SAR for the Alpha variant with the SAR for other circulating variants in Norway during the study period.

\section{MATERIALS AND METHODS}

\section{Study design and study population}

The design of this prospective longitudinal study was based on the WHO Household Transmission Investigation protocol (11). From May to June 2020, and from September 2020 to May 2021, we recruited households of laboratory confirmed COVID-19 cases in the capital/county Oslo and the surrounding county Viken. The course of the pandemic in Oslo/Viken, and of recruitment in this period, are shown in Figure 1A and Figure 1B, respectively. All households with a PCR-confirmed SARS-CoV- 2 case aged $\geq 12$ years, living with at least one other person aged $\geq 2$ years, were eligible for participation. To avoid recruitment of households with co-primary cases, households with more than two members who tested positive on the same date were not eligible, unless the transmission dynamics were known. A further exclusion criterion was added when COVID-19 vaccines became available, whereby households with vaccinated individuals were not eligible.

Primary cases and their household contacts were identified by the municipalities' infection control teams following a positive SARS-CoV-2 PCR test and were subsequently contacted by the study team. Households willing to participate were visited at home, and written informed consent was obtained from the participants and/or their guardians before study inclusion. 
The study was approved by the Regional Ethics Committee in Norway (\#118354).

\section{National COVID-19 isolation and quarantine regulations}

According to the Norwegian COVID-19 regulations, isolation was mandatory for persons with confirmed COVID-19. The isolation should be implemented at home or similar for at least 8-10 days after symptom debut (recommendations varied throughout the study period), lasting at least three days after symptom relief. Asymptomatic cases had to isolate for 10 days after their initial positive PCRtest. In isolation, positive cases were instructed to stay $\geq 2$ meters from other household members, use separate bathrooms, towels, and bedrooms if possible. Household contacts were instructed to quarantine in their homes, maintaining an increased distance to other adults in the household.

\section{Sampling and data collection}

The first home visit for inclusion and sampling was termed Day0, and seven further home visits for sampling were performed during the following 6 weeks (i.e. termed Day3, Day7, Day10, Day14, Day21, Day28, and Day42) (Supplementary Figure 1).

Oropharyngeal (OP) samples and neat saliva samples were gathered from eligible participants on each visit to test for SARS-CoV-2 by RT-qPCR. Health care workers collected OP samples using OP flocked swabs (FLOQSwabs ${ }^{\mathrm{TM}}$ Copan, Italy), in $3 \mathrm{ml}$ UTM (Universal Transport Medium, Copan Italy). Whole blood (Vacuette®EDTA-k2) was collected once for each participant aged $\geq 18$ years for blood typing. Saliva and blood for immunological analyses were also collected at Day0, Day7, Day14, Day28, Day42 and Day180 (not subject of this publication).

All participants were asked to answer a questionnaire on Day0 (Q-D0), to obtain information about the household in general, transmission risk factors, clinical symptoms, and general health status. This questionnaire was adapted from the WHO protocol. The questions on behavioral risk factors in the QD0 related to the period up to 10 days prior to SARS-CoV-2 confirmation of the primary case, and precautionary practices after confirmation. An additional questionnaire (Q-DX) asking about the suspected source of transmission, adherence to isolation/quarantine regulations and self-report of the severity of disease, was answered by participants at the home visit on Day28/Day42 or collected through phone interviews. In addition, a symptom diary adapted from the WHO protocol was completed daily from Day0 to Day28 by all participants.

\section{Laboratory testing}

The laboratory analysis and interpretations were conducted by NIPH. All OP and saliva samples were tested for the presence of SARS-CoV-2 by RT-qPCR. The positive samples were further analyzed by amplicon-based whole genome sequencing (WGS) of SARS-CoV-2 and droplet digital PCR (ddPCR) for absolute quantification, as described in Supplementary Methods. To estimate the viral load, SARSCoV-2 RNA copies per $\mu 1$ eluate was determined by ddPCR using the saliva sample with the lowest cycle of threshold $(\mathrm{Ct})$ value for each participant, if sufficient material was available.

\section{Definition of cases and contacts}

Household contacts were defined as individuals aged $\geq 2$ years who resided with the primary case. A household contact was considered a secondary case if they had a positive PCR test (OP and/or saliva), and their symptom onset/PCR positive test (which ever came first; defined as T0) was within 14 days after $\mathrm{T} 0$ of the primary case. If a household contact had a $\mathrm{T} 0 \geq 2$ days prior to $\mathrm{T} 0$ of the original 
primary case, the household contact was defined as an alternative primary case. If household members had the same T0, or +/- 1 day, they were re-defined as co-primary cases, unless the original primary case had a known source of infection outside of the household.

\section{Study samples included in analysis}

For the main overall SAR analysis, households containing co-primary cases were excluded. Households with alternative primary cases were included in the overall SAR analysis but excluded from the analysis on behavioral factors and preventive measures due to lack of data from the Q-D0 questionnaire (Figure 2). For comparisons between genetic variants, households with the Alpha lineages were compared with non-VOC SARS-CoV-2 viruses, hereby referred to as non-VOC viruses (12), while households with other VOCs were excluded from the analyses (i.e. one household with the Beta variant). One household contact lacked variant data and was assigned the same variant as the primary case.

\section{Data analysis and statistical methods}

The SAR was estimated as the proportion (\%) of household contacts that were defined as confirmed cases (11). Cluster robust standard errors were used to calculate 95\% confidence intervals. The proportion of households with secondary transmission was also estimated. To test for differences in proportions, the Pearson chi-square test statistics was corrected with the second-order correction of Rao and Scott and converted into an F statistic (13).

To account for dependencies within households, a mixed-effect logistic regression model with a household-level random intercept was used to study the associations between potential risk factors for transmission and of infection among the household contacts. The multivariable models were adjusted for age and sex of the household contacts and of the primary cases, and household size. The analysis on associations between SARS-CoV-2 viral load (SARS-CoV-2 RNA copies/ul eluate measured by ddPCR) and symptoms was limited to the confirmed cases. For analyses with all cases, a mixed-effect logistic regression adjusted for age and sex was used, whereas for analyses only done on primary cases logistic regression was used. To study the association between genetic variant and viral load, a mixedeffect linear regression adjusted for age and sex was used. The mean duration of detectable SARSCoV-2 was estimated for household contacts only, as described in Supplementary Methods for children ( $<18$ years) and adults ( $\geq 18$ years), and cluster robust standard errors were used to calculate $95 \%$ confidence intervals. Primary cases were not included in this analysis as the majority were adults (due to the inclusion criteria of the study) and infection was likely detected later in the course of disease for these participants. To estimate the association between duration of detectable SARS-CoV2 by RT-qPCR (in days) and age group, a mixed-effect linear regression was used.

All analyses were performed in STATA/SE 15.0 (StataCorp. College Station, Texas USA). A p-value of $<0.05$ was considered statistically significant (shown in bold in the tables).

\section{RESULTS}

\section{Baseline characteristics of households and participants}

We recruited 70 households, including 216 participants (Figure 2). Ninety eight percent of eligible household members agreed to participate in the study. Five cases were co-primary cases and were excluded together with their 11 household contacts. A total of 65 primary cases/households and their 
135 household contacts (200 participants) were thus eligible for the evaluation of secondary transmission. Among the 65 households, 18 of the primary cases were infected with the Alpha variant, one with the Beta variant and 40 with other circulating non-VOC viruses (Supplementary Table S1). Households with the Alpha variant were recruited between March and May 2021, while households with non-VOC viruses were mainly recruited before February 2021, reflecting the viral circulation in the study area during the recruitment period (Supplementary Figure 2). Sequence data showed the same genetic lineage for all sequenced members within individual households. Demographic and clinical characteristics of the participants in the SAR analyses are shown in Table 1. The median age of the participants was 31 years, and primary cases were generally older than household contacts (38 and 24 years, respectively). About $1 / 3^{\text {rd }}$ of the participants were children aged $<18$ years, while only six were older than 65 . The proportion of males and females was equal, and $51 \%$ were of Nordic ethnicity (but there was considerable missing data for this variable).

The median household size was four, ranging from two to six people, and families with young children constituted $43 \%$ of the households (Table 1). The household size was slightly smaller in households where participants were infected with the Alpha genetic variant (median $=3$ ), compared with households infected with non-VOC viruses $($ median $=4$ ). The remaining characteristics were broadly similar between these two groups.

Of the 200 participants $132(66 \%)$ were infected. Fourteen percent of the confirmed cases were asymptomatic, while $43 \%$ had mild disease and $42 \%$ had a moderate disease, based on their reported symptoms within 14 days of their first positive PCR sample. Few study participants were hospitalized, and all were discharged the following day. There were slightly more asymptomatic cases (22\%) among the Alpha variant participants compared with participants with non-VOC viruses (9\%), although the difference was not significant $(\mathrm{p}=0.09)$ (Supplementary Table S2). Severity also varied with age, with $36 \%$ of children ( $<18$ years) being asymptomatic compared to $8 \%$ of adults $(\mathrm{p}<0.01)$. Children were SARS-CoV-2 RT-qPCR positive for a shorter time period than adults (mean number of days 11.3 (95\% CI 7.6-15.1) and 16.4 (95\% CI 13.5-19.3) respectively, $\mathrm{p}=0.03$ ).

\section{Secondary transmission of COVID-19 in households}

Secondary transmission occurred in $60.0 \%$ of the households in the study (95\% CI 47.4-71.4) (Table 2). The secondary attack rate (SAR) among all household contacts was $49.6 \%$ (95\% CI 37.8-61.5). Secondary transmission was significantly higher in households with the Alpha variant $(83.3 \%, 95 \% \mathrm{CI}$ 55.9-95.2) compared with non-VOC viruses (55.0\% (95\% CI 39.8-70.1), p=0.04). For household contacts, SAR was $77.8 \%$ (95\% CI 49.4-92.6) in households with the Alpha variant, compared with $42.5 \%$ (95\% CI 28.7-57.7) in households with non-VOC viruses, resulting in a significantly higher adjusted odds ratio (OR) for secondary transmission in households with the Alpha variant $(\mathrm{p}=0.03)$ (Table 2).

The median interval from the date of the first positive SARS-CoV-2 test (collected by the municipality for the primary case) and the Day0 visit in the study was 3 days (IQR; 2-4 days). A large proportion of the secondary cases $(38.5 \%)$ were already infected at Day0, while $61.5 \%$ of the secondary cases were detected during study follow-up. The overall serial interval (the number of days between symptom onset of the primary case and of a household contact) was estimated to 4 days (range 1-11, n=50). The median serial interval was similar for the Alpha variant (4 days, range 2-11, $n=17$ ) and non-VOC viruses ( 4 days, range 1-9 days, $n=31$ ). The overall median interval between symptom onset of the primary case and the first RT-qPCR-positive test of a household contact was 3 days (range 1-12, 
$\mathrm{n}=60$ ), and this interval was the same for Alpha (3 days, range 1-11, $\mathrm{n}=25)$ and non-VOC viruses (4 days, range 1-9 days, $\mathrm{n}=33$ ).

\section{Effect of host and household characteristics on secondary transmission}

Neither age (12-39 years compared to $\geq 40$ years) nor sex of the primary case appeared to have an impact on SAR (Table 3). Notably there were few primary cases under the age of 18, therefore it was not possible to study the effect of age on transmission for primary cases aged 12-18 years.

Secondary infection amongst children aged 2-17 years was similar for those aged 18-39 (SAR 47\% and $40 \%$, respectively), while household contacts aged $\geq 40$ years were more likely to be infected (69\%) (Table 3). The sex and blood type of the household contacts did not impact the infection risk. Household contacts living in overcrowded houses had a higher infection risk than those not living in overcrowded houses (SAR 90\% and 52\%, respectively), but the difference was not significant when adjusted for age, sex, and household size. However, the number of overcrowded households was small. Secondary transmission did not differ with household size or number of bathrooms in the household.

Both fever and loss of taste/smell were significantly more common in primary cases with the Alpha variant compared to others (Supplementary Table S3). In addition, the SAR was higher if these symptoms were present (Table 4). If the primary case reported loss of taste/smell, the SAR was $60 \%$ versus $27 \%$, and there was a similar trend for fever (61\% versus $39 \%)$, and a weak trend for cough. Dyspnea in the primary case did not appear to influence the SAR, nor clinical severity.

\section{Role of viral load measured by ddPCR}

As expected, the correlation between viral load (SARS-CoV-2 RNA copies/ $\mu 1$ eluate) determined by ddPCR and the RT-qPCR Ct-values was strong $(r=-0.859, \mathrm{p}<0.001)$. There was a trend that higher viral load measured by ddPCR was associated with increased risk of secondary infection (adjusted OR 3.05 (95\% CI 0.84-11.0), $\mathrm{p}=0.089$ ). Higher viral load was also associated with increased risk of loss of taste/smell (adjusted OR $=1.4$ (95\% CI 1.06-1.85), $\mathrm{p}=0.02)$, and possibly dyspnea $(\mathrm{OR}=1.34(95 \%$ CI 0.96-1.86), $\mathrm{p}=0.08$ ) and cough (adjusted OR 1.37 (95\% CI 0.93-2.01), p=0.11) (Supplementary Table S4). However, despite an OR larger than 1, these associations were not significant when looking at only the primary cases, possibly because of the lower sample size.

The viral load was significantly higher for the Alpha variant than for non-VOC viruses (mean 3.24 $\log _{10}$ and $2.48 \log _{10}$ RNA copies/ $\mu 1$ eluate, respectively) (Figure 3A). We also found a significantly lower viral load in children than in adults (mean $2.09 \log _{10}$ copies/ $\mu 1$ RNA and $2.98 \log _{10} \operatorname{copies} / \mu 1$ RNA, respectively) (Figure 3B), irrespective of virus variant (Figure 3C). The association between viral load and the Alpha variant remained significant in a mixed-effect linear regression model when adjusted for age and sex (adjusted regression coefficient of 0.87 (95\% CI 0.34-1.40), $\mathrm{p}=0.001$ ).

\section{The impact of behavioral factors and precautionary practices on secondary transmission}

None of the contact behaviors between the primary case and the household contacts prior to confirmation of infection of the primary case were significantly associated with SAR (Table 5). Nevertheless, there was a trend that the SAR was higher for contacts who shared a toilet, hugged, kissed, shook/ held hands, slept in the same room and shared a bed with the primary case before infection was confirmed. 
After confirmation of the infection of the primary case, the only precautionary practice to significantly prevent household transmission was sleeping in a separate room from the primary case, with a SAR of $38 \%$, compared to $67 \%$ for those who slept in the same room $(\mathrm{p}=0.048)$ (Table 5). All other precautionary practices tended to lower the SAR, particularly isolation of the primary case, but associations were not statistically significant.

\section{DISCUSSION}

This prospective longitudinal household study with close follow-up and systematic sampling shows a high overall SAR (49.6\%), confirming that households are an important site of transmission. The SAR of the Alpha variant (B.1.1.7 VOC) was significantly higher, at $77.8 \%$, compared with $42.5 \%$ for the other non-VOC viruses dominating in Norway until Feb/March 2021. A significantly higher viral load was found in the saliva of participants with the Alpha variant compared to the non-VOC viruses, which may contribute to the increased transmissibility. Close contact behavior prior to confirmation of infection of the primary case tended to give a higher SAR. However, we showed that SAR was reduced if the primary case slept in a separate room or was isolated from the rest of the household after infection was confirmed.

Our SAR-estimate of $42.5 \%$ for non-VOC viruses is higher than the estimates of around $17 \%$ found in other early reviews $(2,14)$, but is in accordance with another Norwegian household study from the first wave of the pandemic, which estimated a SAR of $47 \%$ based on RT-qPCR and seroconversion (15). Other studies performed in the UK, the Netherlands, and the US in the beginning/middle of 2020 also found similar SARs of 37\%-53\% (16-18). A more recent Norwegian national register-based study found a considerably lower household SAR of only $21 \%$ (19). Register based studies are more sensitive to underreporting, as it is not mandatory to test all household members, which may in turn lead to an underestimation of SAR. In particular, parents may hesitate to test children because of discomfort with nasopharyngeal swabbing. Indeed, Fung et al. (14) showed that studies that tested household members more frequently observed higher SARs. None of the aforementioned studies sequenced positive virus samples or quantified viral load, and most were performed before the Alpha strain appeared.

The Alpha variant has been shown to be generally more transmissible than non-VOC viruses $(7,20)$ and our study demonstrates this in a household setting. Our finding that SAR is significantly higher in households with the Alpha variant compared with non-VOC viruses, is in agreement with previous household studies (21-23). However, we estimated a substantially higher SAR (77.3\%) for the Alpha variant than was reported in these other studies $(25.1 \%, 38 \%$, and $42 \%)$, probably because they were registry based. In our study, the extensive testing over several weeks with both salivary and OP samples, including testing of small children, probably enabled identification of most infected cases in the households, and thus contributed to our higher SAR estimates both overall and for the Alpha variant in particular. We found no difference between the median serial interval for the Alpha variant and the non-VOC viruses, which is in accordance with other studies (24).

Previous estimates of SAR in children and different age groups, have been conflicting (2, 18, 25-29), probably due to various biases, as discussed by Goldstein and colleagues (29). We found that the risk of transmission was similar for children ( $<18$ years) and adults below 40 years, while household contacts aged $\geq 40$ years had increased risk of secondary transmission. The age of the primary case was not associated with the risk of secondary transmission in the household. However, most of the primary cases in our study were $>18$ years old. 
We used ddPCR to accurately assess SARS-CoV-2 viral load and to avoid potential inference from inhibitory substances which may influence the results when using RT-qPCR for quantification (9). Previous studies have been conflicting regarding the relationship between viral variant and viral load $(21,30,31)$. Our results support that the Alpha variant is associated with a higher viral load. It has been argued that the time of sampling may obscure the comparison of viral loads between variants (30). In our study, frequent sampling enabled the selection of the sample with the lowest Ct-value for the quantification of viral load by ddPCR, thus reducing the effect of timing of sampling collection. Furthermore, this finding was consistent when the analysis was limited to the household contacts only (data not shown), for whom sampling was performed earlier in the course of infection compared with the primary cases. We also demonstrated both lower viral load and shorter duration of viral detection in children compared with adults, which in accordance with some studies (32-34), while others have shown no difference in viral load (35). Our results may suggest that it is more difficult to detect active infection in children, and that the timing of the test is of importance. Further, loss of taste/smell in primary cases, a distinctive feature of COVID-19 infection (36), was associated with a significant increase in SAR, which may in part be explained by an increased viral load as observed in participants reporting loss of taste/smell. The association between taste/smell impairment and higher viral load has also been found by others $(37,38)$. This may be dependent on variant, as we found that loss of taste/smell was more common amongst primary cases with the Alpha variant.

Most contact behavior such as kissing, appeared to slightly increase the odds of secondary transmission, although not significantly. We found that sleeping separately from the primary case after confirmation of infection prevented secondary infection, as shown previously (28). Other measures reducing contact with the primary case, especially isolation, also seemed to lower secondary transmission. This is in contrast to a similar household study by Miller and colleagues (25) which found no effect, possibly explained by transmission already occurring prior to laboratory confirmation of the primary case. Although we also observed that a high fraction of the transmission had occurred quite early, our findings still support the importance of starting precautionary practices after infection.

The present study has several limitations. First, our sample size was small, which limited the comparison between factors associated with the Alpha variant and other non-VOC viruses. Further, the study was not initially designed to evaluate differences in SAR between variants, and the dominance of the variants differed during the study period. We can therefore not exclude that climate, people's behavior, or other factors, could have influenced our results. Quarantine and isolation guidelines were similar throughout the whole study period; thus, we assume that this has not significantly influenced our results. Finally, the age span of participants was limited, with few elderly individuals and mostly adult primary cases.

In conclusion, in this prospective longitudinal household study, we found an overall secondary attack rate for household contacts of $49.6 \%$. The SAR was considerably higher for the Alpha variant $(77.8 \%)$ than for non-VOC viruses, indicating a very high level of household transmission, possibly mediated by the higher viral load, for this VOC. We also showed that age affects secondary infection, with higher SAR in household contacts older than 40 years. Implementation of precautionary measures after detection of the first SARS-CoV-2 case seems to reduce household transmission, in particular sleeping separately from the primary case. However, preventing transmission within a household will become increasingly difficult with the emergence of more contagious variants. Our results emphasize the role of households in the transmission of SARS-CoV-2 in the Norwegian population and the 
medRxiv preprint doi: https://doi.org/10.1101/2021.08.15.21261478; this version posted September 22, 2021. The copyright holder for this preprint (which was not certified by peer review) is the author/funder, who has granted medRxiv a license to display the preprint in perpetuity. All rights reserved. No reuse allowed without permission.

importance of strict adherence to the isolation and quarantine regulations in all households with a confirmed case.

\section{Declaration of Competing Interest}

The authors declare no conflicts of interest. 


\section{Acknowledgements}

We want to thank all the participants who willingly let us into their homes and provided frequent samples over a long period of time. We also want to acknowledge the following; our eminent health care workers who visited and sampled all the participants (Marit F. Killengren, Torunn R. Strand, Hena Anawar, Christina Nitschke, Kristina Maudal); the head of Section for Influenza (Karoline Bragstad); the coordinators, technicians and bioinformaticians at the Department of Virology, the Department of Bacteriology, the Reception of Biological Samples; the engineers at the Department of Method Development and Analytics; the municipalities' infection control teams in Oslo/Viken for their contribution to recruitment of participants; WHO for developing the protocol which formed the basis for the study.

This research was solely funded by the Norwegian Institute of Public Health (NIPH) and received no specific grant from any funding agency, commercial or not-for-profit sectors.

\section{REFERENCES}

1. Norwegian Institute of Public Health (NIPH). COVID-19 Ukesrapport - uke 342021 [Sep, 2021]. Available from:

https://www.fhi.no/contentassets/8a971e7b0a3c4a06bdbf381ab52e6157/vedlegg/2021/ukerapportuke-34-23.08---29.08.21.pdf.

2. Madewell ZJ, Yang Y, Longini IM, Jr., Halloran ME, Dean NE. Household Transmission of SARS-CoV-2: A Systematic Review and Meta-analysis. JAMA Netw Open. 2020 Dec 1;3(12):e2031756. PubMed PMID: 33315116. Pubmed Central PMCID: PMC7737089. Epub 2020/12/15.

3. Rambaut A, Loman N, Pybus O, Barclay W, Barrett J, Carabelli A, et al. Preliminary genomic characterisation of an emergent SARS-CoV-2 lineage in the UK defined by a novel set of spike mutations. Genom Epidemiol. 2020.

4. Chand M, Hopkins S, Dabrera G, Achison C, Barclay W, Ferguson N. Investigation of novel SARS-COV-2 variant Variant of Concern 202012/01. Public Health England, . 2020.

5. Norwegian Institute of Public Health (NIPH). COVID-19 Ukesrapport - uke 282021 [Sep, 2021]. Available from:

https://www.fhi.no/contentassets/8a971e7b0a3c4a06bdbf381ab52e6157/vedlegg/2021/ukerapportuke-28-12.07---18.07.21.pdf.

6. Piantham C, Linton NM, Nishiura H, Ito K. Estimating the elevated transmissibility of the B.1.1.7 strain over previously circulating strains in England using GISAID sequence frequencies. medRxiv. 2021:2021.03.17.21253775.

7. Davies NG, Abbott S, Barnard RC, Jarvis CI, Kucharski AJ, Munday JD, et al. Estimated transmissibility and impact of SARS-CoV-2 lineage B.1.1.7 in England. Science. 2021;372(6538):eabg3055.

8. Volz E, Mishra S, Chand M, Barrett JC, Johnson R, Geidelberg L, et al. Transmission of SARS-CoV-2 Lineage B.1.1.7 in England: Insights from linking epidemiological and genetic data. medRxiv. 2021:2020.12.30.20249034. 
9. Dyavar SR, Ye Z, Byrareddy SN, Scarsi KK, Winchester LC, Weinhold JA, et al. Normalization of cell associated antiretroviral drug concentrations with a novel RPP30 droplet digital PCR assay. Scientific Reports. 2018 2018/02/26;8(1):3626.

10. Kim KB, Choi H, Lee GD, Lee J, Lee S, Kim Y, et al. Analytical and Clinical Performance of Droplet Digital PCR in the Detection and Quantification of SARS-CoV-2. Mol Diagn Ther. 2021 Sep;25(5):617-28. PubMed PMID: 34319580. Pubmed Central PMCID: PMC8316104 Sung-Yeon Cho, Dong-Gun Lee, and Myungshin Kim have no conflicts of interest that are directly relevant to the content of this article. Epub 2021/07/29. eng.

11. World Health Organization (WHO). Household transmission investigation protocol for 2019novel coronavirus (COVID-19) infection Feb, 2020 [updated March, 2020]. Available from: https://www.who.int/publications/i/item/household-transmission-investigation-protocol-for-2019novel-coronavirus-(2019-ncov)-infection.

12. European Centre for Disease Prevention and Control (ECDC). SARS-CoV-2 variants of concern as of 24 June 2021 June. 2021 [June, 2021]. Available from: https://www.ecdc.europa.eu/en/covid-19/variants-concern

13. Rao JNK, Scott AJ. On Chi-Squared Tests for Multiway Contingency Tables with Cell Proportions Estimated from Survey Data. The Annals of Statistics. 1984;12(1):46-60.

14. Fung HF, Martinez L, Alarid-Escudero F, Salomon JA, Studdert DM, Andrews JR, et al. The household secondary attack rate of SARS-CoV-2: A rapid review. Clin Infect Dis. 2020 Oct 12. PubMed PMID: 33045075. Pubmed Central PMCID: PMC7665336. Epub 2020/10/13.

15. Kuwelker K, Zhou F, Blomberg B, Lartey S, Brokstad KA, Trieu MC, et al. Attack rates amongst household members of outpatients with confirmed COVID-19 in Bergen, Norway: A caseascertained study. Lancet Reg Health Eur. 2021 Apr;3:100014. PubMed PMID: 33871470. Pubmed Central PMCID: PMC8009692. Epub 2021/04/20. eng.

16. Bernal JL, Panagiotopoulos N, Byers C, Garcia Vilaplana T, Boddington N, Zhang X-S, et al. Transmission dynamics of COVID-19 in household and community settings in the United Kingdom. medRxiv. 2020:2020.08.19.20177188.

17. Grijalva CG, Rolfes MA, Zhu Y, McLean HQ, Hanson KE, Belongia EA, et al. Transmission of SARS-COV-2 Infections in Households - Tennessee and Wisconsin, April-September 2020. MMWR Morb Mortal Wkly Rep. 2020 Nov 6;69(44):1631-4. PubMed PMID: 33151916. Pubmed Central PMCID: PMC7643897 Journal Editors form for disclosure of potential conflicts of interest. Carlos G. Grijalva reports personal consulting fees from Sanofi, Merck, and Pfizer; grants from Sanofi, Campbell Alliance, the National Institutes of Health, the Agency for HealthCare Research and Quality, and a contract from the Food and Drug Administration, outside the submitted work. Natasha B. Halasa reports grants from Sanofi and Quidel and personal fees from Genetech, outside the submitted work. No other potential conflicts of interest were disclosed. Epub 2020/11/06.

18. Reukers DFM, van Boven M, Meijer A, Rots N, Reusken C, Roof I, et al. High infection secondary attack rates of SARS-CoV-2 in Dutch households revealed by dense sampling. Clinical Infectious Diseases. 2021.

19. Telle K, Jørgensen SB, Hart R, Greve-Isdahl M, Kacelnik O. Secondary attack rates of COVID-19 in Norwegian families: a nation-wide register-based study. European Journal of Epidemiology. 2021 2021/05/25.

20. Volz E, Mishra S, Chand M, Barrett JC, Johnson R, Geidelberg L, et al. Assessing transmissibility of SARS-CoV-2 lineage B.1.1.7 in England. Nature. 2021 May;593(7858):266-9. PubMed PMID: 33767447. Epub 2021/03/27. eng. 
medRxiv preprint doi: https://doi.org/10.1101/2021.08.15.21261478; this version posted September 22, 2021. The copyright holder for this

21. Lyngse FP, Mølbak K, Skov RL, Christiansen LE, Mortensen LH, Albertsen M, et al. Increased Transmissibility of SARS-CoV-2 Lineage B.1.1.7 by Age and Viral Load: Evidence from Danish Households. medRxiv. 2021:2021.04.16.21255459.

22. Buchan SA, Tibebu S, Daneman N, Whelan M, Vanniyasingam T, Murti M, et al. Increased household secondary attacks rates with Variant of Concern SARS-CoV-2 index cases. Clin Infect Dis. 2021 Jun 9. PubMed PMID: 34105720. Pubmed Central PMCID: PMC8384411. Epub 2021/06/10. eng.

23. Lindstrøm JC, Engebretsen S, Bråthen Kristoffersen A, Øyvind Isaksson Rø G, Palomares AD-L, Eng $\varnothing-M o n s e n ~ K$, et al. Increased transmissibility of the B.1.1.7 SARS-CoV-2 variant: Evidence from contact tracing data in Oslo, January to February 2021. medRxiv. 2021:2021.03.29.21254122.

24. Geismar C, Fragaszy E, Nguyen V, Fong WLE, Shrotri M, Beale S, et al. Serial interval of COVID-19 and the effect of Variant B.1.1.7: analyses from a prospective community cohort study (Virus Watch). medRxiv. 2021:2021.05.17.21257223.

25. Miller E, Waight PA, Andrews NJ, McOwat K, Brown KE, Katja H, et al. Transmission of SARS-CoV-2 in the household setting: A prospective cohort study in children and adults in England. Journal of Infection.

26. McLean HQ, Grijalva CG, Hanson KE, Zhu Y, Deyoe JE, Meece JK, et al. Household Transmission and Clinical Features of SARS-CoV-2 Infections by Age in 2 US Communities. medRxiv. 2021:2021.08.16.21262121.

27. Spielberger BD, Goerne T, Geweniger A, Henneke P, Elling R. Intra-Household and CloseContact SARS-CoV-2 Transmission Among Children - a Systematic Review. Front Pediatr. 2021;9:613292-. PubMed PMID: 33898355. eng.

28. Ng OT, Marimuthu K, Koh V, Pang J, Linn KZ, Sun J, et al. SARS-CoV-2 seroprevalence and transmission risk factors among high-risk close contacts: a retrospective cohort study. The Lancet Infectious Diseases. 2021;21(3):333-43.

29. Goldstein E, Lipsitch M, Cevik M. On the Effect of Age on the Transmission of SARS-CoV-2 in Households, Schools, and the Community. J Infect Dis. 2021 Feb 13;223(3):362-9. PubMed PMID: 33119738. Pubmed Central PMCID: PMC7665686. Epub 2020/10/30. eng.

30. Cosentino G, Bernard M, Ambroise J, Giannoli J-M, Guedj J, Débarre F, et al. SARS-CoV-2 viral dynamics in infections with Alpha and Beta variants of concern in the French community. Journal of Infection. 2021 2021/07/28/.

31. Kissler SM, Fauver JR, Mack C, Tai CG, Breban MI, Watkins AE, et al. Densely sampled viral trajectories for SARS-CoV-2 variants alpha (B.1.1.7) and epsilon (B.1.429). medRxiv. 2021:2021.02.16.21251535.

32. Maltezou HC, Vorou R, Papadima K, Kossyvakis A, Spanakis N, Gioula G, et al. Transmission dynamics of SARS-CoV-2 within families with children in Greece: A study of 23 clusters. Journal of Medical Virology. 2021;93(3):1414-20.

33. Yan D, Zhang X, Chen C, Jiang D, Liu X, Zhou Y, et al. Characteristics of Viral Shedding Time in SARS-CoV-2 Infections: A Systematic Review and Meta-Analysis. Frontiers in Public Health. 2021 2021-March-19;9(209). English.

34. Cendejas-Bueno E, Romero-Gómez MP, Escosa-García L, Jiménez-Rodríguez S, Mingorance J, García-Rodríguez J. Lower nasopharyngeal viral loads in pediatric population. The missing piece to understand SARS-CoV-2 infection in children? Journal of Infection. 2021 2021/08/01/;83(2):e18-e9. 
medRxiv preprint doi: https://doi.org/10.1101/2021.08.15.21261478; this version posted September 22, 2021. The copyright holder for this preprint (which was not certified by peer review) is the author/funder, who has granted medRxiv a license to display the preprint in perpetuity. All rights reserved. No reuse allowed without permission.

35. Madera S, Crawford E, Langelier C, Tran NK, Thornborrow E, Miller S, et al.

Nasopharyngeal SARS-CoV-2 viral loads in young children do not differ significantly from those in older children and adults. Scientific Reports. 2021 2021/02/04;11(1):3044.

36. Tong JY, Wong A, Zhu D, Fastenberg JH, Tham T. The Prevalence of Olfactory and Gustatory Dysfunction in COVID-19 Patients: A Systematic Review and Meta-analysis. Otolaryngol Head Neck Surg. 2020 Jul;163(1):3-11. PubMed PMID: 32369429. Epub 2020/05/06. eng.

37. Jain A, Pandey AK, Kaur J, Kumar L, Singh M, Das S, et al. Is there a correlation between viral load and olfactory \& taste dysfunction in COVID-19 patients? Am J Otolaryngol. 2021 MayJun;42(3):102911. PubMed PMID: 33476975. Pubmed Central PMCID: PMC7836834. Epub 2021/01/22. eng.

38. Nakagawara K, Masaki K, Uwamino Y, Kabata H, Uchida S, Uno S, et al. Acute onset olfactory/taste disorders are associated with a high viral burden in mild or asymptomatic SARS-CoV-2 infections. Int J Infect Dis. 2020 Oct;99:19-22. PubMed PMID: 32726723. Pubmed Central PMCID:

PMC7382961. Epub 2020/07/30. eng.

\section{Corresponding author contact information}

Lisbeth Meyer Næss, MSc, PhD

Address: Division of Infection Control, Norwegian Institute of Public Health, P.O.Box 222 Skøyen; 0213 Oslo, Norway

E-mail address: Lisbeth.ness@fhi.no

Phone number: +47 21076526 
medRxiv preprint doi: https://doi.org/10.1101/2021.08.15.21261478; this version posted September 22, 2021. The copyright holder for this preprint (which was not certified by peer review) is the author/funder, who has granted medRxiv a license to display the preprint in perpetuity.

All rights reserved. No reuse allowed without permission.

Table 1. Demographic and clinical characteristics of all included participants and households, and Alpha variant and non-VOC virus households

\begin{tabular}{|c|c|c|c|c|c|c|c|}
\hline \multirow[b]{2}{*}{$\begin{array}{l}\text { Participant } \\
\text { characteristics }^{\mathrm{a}}\end{array}$} & \multirow{2}{*}{$\begin{array}{c}\text { All } \\
\text { participants } \\
(\mathrm{N}=\mathbf{2 0 0})\end{array}$} & \multicolumn{2}{|c|}{ All households (HH) } & \multicolumn{2}{|c|}{$\begin{array}{l}\text { Alpha variant } \\
\text { households }\end{array}$} & \multicolumn{2}{|c|}{$\begin{array}{l}\text { Non-VOC virus } \\
\text { households }\end{array}$} \\
\hline & & $\begin{array}{c}\text { Primary } \\
\text { cases } \\
(\mathrm{N}=65)\end{array}$ & $\begin{array}{c}\mathrm{HH} \\
\text { contacts } \\
(\mathrm{N}=135)\end{array}$ & $\begin{array}{c}\text { Primary } \\
\text { cases } \\
(\mathbf{N}=18)\end{array}$ & $\begin{array}{c}\mathrm{HH} \\
\text { contacts } \\
(\mathrm{N}=\mathbf{3 6})\end{array}$ & $\begin{array}{c}\text { Primary } \\
\text { cases } \\
(\mathrm{N}=\mathbf{4 0})\end{array}$ & $\begin{array}{c}\text { HH } \\
\text { contacts } \\
(\mathrm{N}=\mathbf{8 7})\end{array}$ \\
\hline \multicolumn{8}{|l|}{ Age (years) } \\
\hline Median (range) & $31(2-73)$ & $38(2-71)^{\mathrm{b}}$ & $24(2-73)$ & $38(2-68)^{b}$ & $22(2-63)$ & $38(15-68)$ & $24(2-70)$ \\
\hline $2-17, \mathrm{n}(\%)$ & $63(31.5)$ & $3(4.6)$ & $60(44.4)$ & $2(11.1)$ & $16(44.4)$ & $1(2.5)$ & $39(44.8)$ \\
\hline$\geq 18, \mathrm{n}(\%)$ & $137(68.8)$ & $62(95.4)$ & $75(55.6)$ & $16(88.9)$ & $20(55.6)$ & $39(97.5)$ & $48(55.2)$ \\
\hline \multicolumn{8}{|l|}{ Sex } \\
\hline Female, n (\%) & $104(52)$ & 35 (53.9) & $69(51.1)$ & $10(55.6)$ & $16(44.4)$ & 19 (47.5) & $49(56.3)$ \\
\hline Male, n (\%) & $96(48)$ & $30(46.1)$ & 66 (48.9) & $8(44.4)$ & $20(55.6)$ & $21(52.5)$ & $38(43.7)$ \\
\hline \multicolumn{8}{|l|}{ Ethnicity $^{\mathrm{c}}$} \\
\hline Nordic, n (\%) & $101(50.5)$ & - & - & - & - & - & - \\
\hline Part Nordic, n (\%) & $24(12)$ & - & - & - & - & - & - \\
\hline Other, n (\%) & $7(3.5)$ & - & - & - & - & - & - \\
\hline missing, $n(\%)$ & $68(34)$ & - & - & - & - & - & - \\
\hline \multicolumn{8}{|l|}{ Chronic illness $^{\mathrm{d}}$} \\
\hline yes, n (\%) & $33(16.5)$ & $13(20.0)$ & $20(14.8)$ & $4(22.2)$ & $4(11.1)$ & $7(17.5)$ & $14(16.1)$ \\
\hline no, n $(\%)$ & $165(82.5)$ & $52(80.0)$ & $113(83.7)$ & $14(77.8)$ & $32(88.9)$ & $33(82.5)$ & $71(81.6)$ \\
\hline missing, $n(\%)$ & $2(1.0)$ & & $2(1.5)$ & & $0(0)$ & & $2(2.3)$ \\
\hline \multicolumn{8}{|l|}{$\begin{array}{l}\text { Profession } \\
\text { (age } \geq 16 y r s)\end{array}$} \\
\hline Healthcare, n (\%) & $28(19.3)$ & $13(20.0)$ & $15(18.1)$ & $9(23.1)$ & $10(18.5)$ & $3(18.8)$ & $3(13.6)$ \\
\hline Other, n (\%) & $117(80.7)$ & $49(79.0)$ & $68(91.9)$ & $30(76.9)$ & $44(81.5)$ & $13(81.3)$ & $19(86.4)$ \\
\hline $\begin{array}{l}\text { Household } \\
\text { characteristics }\end{array}$ & & All ho & seholds & $\begin{array}{l}\text { Alph: } \\
\text { hou }\end{array}$ & $\begin{array}{l}\text { ariant } \\
\text { lolds }\end{array}$ & $\begin{array}{r}\text { Non-VC } \\
\text { hous }\end{array}$ & $\begin{array}{l}\text { virus } \\
\text { olds }\end{array}$ \\
\hline \multicolumn{8}{|l|}{ Household size } \\
\hline 2 persons, n (\%) & - & \multicolumn{2}{|c|}{$24(36.9)$} & \multicolumn{2}{|c|}{$6(33.3)$} & \multicolumn{2}{|c|}{$15(37.5)$} \\
\hline 3 persons, n $(\%)$ & - & \multicolumn{2}{|c|}{$9(13.9)$} & \multicolumn{2}{|c|}{$11(61.1)$} & \multicolumn{2}{|c|}{$9(22.5)$} \\
\hline 4 persons, n (\%) & - & \multicolumn{2}{|c|}{22 (33.9) } & \multicolumn{2}{|c|}{$1(5.6)$} & \multicolumn{2}{|c|}{$7(17.5)$} \\
\hline 5-6 persons, $\mathrm{n}(\%)$ & - & \multicolumn{2}{|c|}{$10(15.3)$} & \multicolumn{2}{|c|}{$0(0)$} & \multicolumn{2}{|c|}{$9(22.5)$} \\
\hline \multicolumn{8}{|l|}{ Young children $^{\mathrm{e}}$} \\
\hline yes, n (\%) & - & \multicolumn{2}{|c|}{$28(43.1)$} & \multicolumn{2}{|c|}{$9(50)$} & \multicolumn{2}{|c|}{$16(40)$} \\
\hline no, n $(\%)$ & - & \multicolumn{2}{|c|}{$37(56.9)$} & \multicolumn{2}{|c|}{$9(50)$} & \multicolumn{2}{|c|}{$24(60)$} \\
\hline
\end{tabular}

Abbreviations: HH; households, non-VOC; non-Variant of Concern

a the total number of households and household contacts in the Alpha variant vs "non-VOC viruses" comparison does not add up to the "overall" total of 200, as some sequence data was lacking, and VOCs other than Alpha were excluded (Figure 2).

${ }^{\mathrm{b}}$ includes an alternative primary case, aged 2 years.

${ }^{\mathbf{c}}$ due to missing data, ethnicity was not stratified according to genetic variant.

d cancer, diabetes, cardiovascular disease, high blood pressure, chronic lung disease, asthma, obesity, chronic liver disease, chronic hematological disorder, chronic kidney disease, chronic neurological impairment/disease, HIV, immunosuppressed, organ or bone marrow recipient.

${ }^{\mathrm{e}}$ households with minimum one child $\leq 12$ years old. 
medRxiv preprint doi: https://doi.org/10.1101/2021.08.15.21261478; this version posted September 22, 2021. The copyright holder for this preprint (which was not certified by peer review) is the author/funder, who has granted medRxiv a license to display the preprint in perpetuity. All rights reserved. No reuse allowed without permission.

Table 2. Comparison of transmission rates for all households and household contacts, and for Alpha variant versus non-VOC viruses

\begin{tabular}{|c|c|c|c|c|c|c|c|}
\hline $\begin{array}{l}\text { Households }^{\mathrm{a}} \\
\text { with } \\
\text { transmission }\end{array}$ & $\begin{array}{c}\text { \% with transmission, } \\
\quad 95 \% \mathrm{CI}\end{array}$ & $\begin{array}{l}\mathbf{P C R}^{+} \\
(\mathbf{n}) /(\mathbf{N})\end{array}$ & $\begin{array}{c}\text { p- } \\
\text { value }^{b}\end{array}$ & $\begin{array}{c}\text { Crude OR, } \\
95 \% \text { CI }\end{array}$ & $\begin{array}{c}\text { p- } \\
\text { value }\end{array}$ & & \\
\hline All variants & $60.0(47.4-71.4)$ & $39 / 65$ & & & & & \\
\hline $\begin{array}{l}\text { Non-VOC } \\
\text { viruses }\end{array}$ & $55.0(39.8-70.1)$ & $22 / 40$ & & 1 (Ref) & & - & - \\
\hline $\begin{array}{l}\text { Alpha } \\
\text { variant }\end{array}$ & $83.3(55.9-95.2)$ & $15 / 18$ & 0.04 & $4.24\left(0-4.2 \times 10^{32}\right)$ & 0.04 & - & - \\
\hline $\begin{array}{l}\text { Household } \\
\text { contact }^{\mathrm{c}}\end{array}$ & $\begin{array}{l}\text { SAR \%, } \\
95 \% \text { CI }\end{array}$ & $\begin{array}{l}\mathbf{P C R}^{+} \\
(\mathbf{n}) /(\mathbf{N})\end{array}$ & $\begin{array}{c}\text { p- } \\
\text { value }^{b}\end{array}$ & $\begin{array}{c}\text { Crude OR, } \\
95 \% \text { CI }\end{array}$ & $\begin{array}{c}\text { p- } \\
\text { value }\end{array}$ & $\begin{array}{c}\text { Adjusted OR }{ }^{\mathrm{d}}, \\
95 \% \mathrm{CI}\end{array}$ & $\begin{array}{c}\text { p- } \\
\text { value }\end{array}$ \\
\hline All variants & $49.6(37.8-61.5)$ & $67 / 135$ & & & & & \\
\hline $\begin{array}{l}\text { Non-VOC } \\
\text { viruses }\end{array}$ & $42.5(28.7-57.7)$ & $37 / 87$ & & 1 (Ref) & & 1 (Ref) & \\
\hline $\begin{array}{l}\text { Alpha } \\
\text { variant }\end{array}$ & $77.8(49.4-92.6)$ & $28 / 36$ & 0.02 & $65.7(1.74-2481)$ & 0.02 & $\begin{array}{c}468 \\
\left(1.8-1.2 \times 10^{5}\right)\end{array}$ & $\mathbf{0 . 0 3}$ \\
\hline
\end{tabular}

Abbreviations: non-VOC; non-Variant of Concern

${ }^{a}$ including 65 households for all variants, and 18 households with Alpha variant, and 40 households with non-VOC viruses.

b comparison of Alpha variant with non-VOC viruses. Pearson chi ${ }^{2}$ test statistics was corrected with the second-order correction of Rao and Scott and converted into an F statistic

${ }^{c}$ households with at least one confirmed case among its household contacts.

d adjusted for the age and sex of the primary case and household contacts, and household size (number of persons per household). 
medRxiv preprint doi: https://doi.org/10.1101/2021.08.15.21261478; this version posted September 22, 2021. The copyright holder for this preprint (which was not certified by peer review) is the author/funder, who has granted medRxiv a license to display the preprint in perpetuity.

All rights reserved. No reuse allowed without permission.

Table 3. Secondary attack rates (SAR) and odds ratios (OR) for secondary infection of all household contacts $(\mathrm{N}=135)$ according to characteristics of primary case, household contact characteristics, and household characteristics.

\begin{tabular}{|c|c|c|c|c|c|c|c|}
\hline Characteristic & $\begin{array}{l}\text { SAR \%, } \\
(95 \% \text { CI })\end{array}$ & $\begin{array}{l}\text { p- } \\
\text { value }^{a}\end{array}$ & $\begin{array}{l}\operatorname{PCR}^{+}(\mathbf{n}) / \\
\text { total }(\mathbf{N})\end{array}$ & $\begin{array}{l}\text { Crude OR } \\
(95 \% \text { CI })\end{array}$ & $\begin{array}{l}\text { p- } \\
\text { value }\end{array}$ & $\begin{array}{l}\text { Adjusted OR } \\
(95 \% \mathrm{CI})\end{array}$ & $\begin{array}{l}p- \\
\text { value }\end{array}$ \\
\hline & \multicolumn{7}{|c|}{ PRIMARY CASE CHARACTERISTICS } \\
\hline \multicolumn{8}{|l|}{ Age (yrs) } \\
\hline $12-39^{c}$ & $47(31-64)$ & & $33 / 70$ & 1 (Ref) & & 1 (Ref) & \\
\hline$\geq 40$ & $52(35-69)$ & 0.67 & $34 / 65$ & $2.30(0.25-21.1)$ & 0.46 & $1.6(0.15-16.9)$ & 0.70 \\
\hline \multicolumn{8}{|l|}{ Sex } \\
\hline Female & $46(30-63)$ & & $29 / 63$ & 1 (Ref) & & 1 (Ref) & \\
\hline Male & $53(35-70)$ & 0.58 & $38 / 72$ & $1.51(0.18-12.7)$ & 0.71 & $1.7(0.15-18.7)$ & 0.68 \\
\hline & \multicolumn{7}{|c|}{ HOUSEHOLD CONTACT CHARACTERISTICS } \\
\hline
\end{tabular}

\begin{tabular}{|c|c|c|c|c|c|c|c|}
\hline \multicolumn{8}{|l|}{ Age (yrs) } \\
\hline $2-17 y r$ & $47(31-63)$ & & $28 / 60$ & 1 (Ref) & & 1 (Ref) & \\
\hline $18-39$ & $40(25-56)$ & & $17 / 43$ & $0.31(0.05-2.04)$ & 0.23 & $0.18(0.02-1.33)$ & 0.09 \\
\hline$\geq 40$ & $69(49-83)$ & 0.03 & $22 / 32$ & $8.03(1.15-56.2)$ & 0.04 & $7.53(1.07-52.8)$ & 0.04 \\
\hline \multicolumn{8}{|l|}{ Sex } \\
\hline Female & $52(38-66)$ & & $36 / 69$ & 1 (Ref) & & 1 (Ref) & \\
\hline Male & $47(32-62)$ & 0.55 & $31 / 66$ & $0.81(0.22-3.01)$ & 0.76 & $0.97(0.24-3.91)$ & 0.96 \\
\hline \multicolumn{8}{|c|}{ Blood type ( $\geq 18 y r s)$} \\
\hline $\mathrm{O}$ & $48(27-69)$ & & $10 / 21$ & 1 (Ref) & & 1 (Ref) & \\
\hline A & $56(37-73)$ & & $18 / 32$ & $1.45(0.38-5.5)$ & 0.59 & $1.41(0.40-4.96)$ & 0.59 \\
\hline $\mathrm{AB}$ & $33(0-100)$ & & $1 / 3$ & $0.49(0.02-10.3)$ & 0.64 & $0.40(0.02-6.47)$ & 0.52 \\
\hline B & $71(22-96)$ & 0.61 & $5 / 7$ & $3.03(0.32-28.3)$ & 0.33 & $3.02(0.41-22.5)$ & 0.28 \\
\hline \multicolumn{8}{|c|}{ HOUSEHOLD CHARACTERISTICS } \\
\hline \multicolumn{8}{|c|}{ Household size } \\
\hline 2 pers & $54(33-74)$ & & $13 / 24$ & 1 (Ref) & & 1 (Ref) & \\
\hline 3 pers & $59(27-84)$ & & $10 / 17$ & $1.72(0.06-53.0)$ & 0.76 & $2.0(0.05-88)$ & 0.71 \\
\hline 4 pers & $47(28-68)$ & & $28 / 59$ & $0.48(0.03-7.72)$ & 0.61 & $0.8(0.04-17)$ & 0.88 \\
\hline $5-6$ pers & $46(20-74)$ & 0.87 & $16 / 35$ & $0.48(0.15-18.6)$ & 0.68 & $0.7(0.02-29)$ & 0.84 \\
\hline \multicolumn{8}{|c|}{ Overcrowding $^{d}$} \\
\hline No & $52(37-66)$ & & $47 / 91$ & 1 (Ref) & & 1 (Ref) & \\
\hline Yes & $\begin{array}{l}90 \\
(24-100)\end{array}$ & 0.01 & $9 / 10$ & $\begin{array}{l}122.7 \\
(0.16-94464)\end{array}$ & 0.16 & $\begin{array}{l}480.9 \\
\left(0.11-2 \times 10^{6}\right)\end{array}$ & 0.15 \\
\hline \multicolumn{8}{|c|}{ Number of bathrooms ${ }^{\mathrm{e}}$} \\
\hline 1 & $58(39-75)$ & & $36 / 62$ & 1 (Ref) & & 1 (Ref) & \\
\hline$\geq 2$ & $44(27-61)$ & 0.25 & $27 / 62$ & $0.2(0.02-2.7)$ & 0.25 & $0.1(0.01-2.2)$ & 0.17 \\
\hline \multicolumn{8}{|c|}{ Abbreviations: SAR; Secondary Attack Rate, OR; Odds Ratio, CI; Confidence Interval } \\
\hline \multicolumn{8}{|c|}{$\begin{array}{l}\text { a Pearson } \text { chi }^{2} \text { test statistics was corrected with the second-order correction of Rao and Scott and converted into an F statistic } \\
\text { b adjusted for the age and sex of the primary case and household contacts, and household size (number of persons per } \\
\text { household), unless this was the factor being analyzed. }\end{array}$} \\
\hline
\end{tabular}


medRxiv preprint doi: https://doi.org/10.1101/2021.08.15.21261478; this version posted September 22, 2021. The copyright holder for this preprint (which was not certified by peer review) is the author/funder, who has granted medRxiv a license to display the preprint in perpetuity. All rights reserved. No reuse allowed without permission.

Table 4. Secondary attack rates (SAR) and odds ratios (OR) for secondary infection for all household contacts $(\mathrm{N}=135)$ according to clinical severity and symptoms of primary case.

\begin{tabular}{|c|c|c|c|c|c|c|c|}
\hline & $\begin{array}{l}\text { SAR \% } \\
(95 \% \text { CI })\end{array}$ & $\begin{array}{c}\mathbf{P C R}^{+} \\
(\mathbf{n}) / \\
\text { total }(\mathbf{N})\end{array}$ & $\begin{array}{c}\text { p- } \\
\text { value }^{a}\end{array}$ & $\begin{array}{l}\text { Crude OR } \\
(95 \% \text { CI })\end{array}$ & $\begin{array}{c}\text { p- } \\
\text { value }\end{array}$ & $\begin{array}{l}\text { Adjusted }^{\mathrm{b}} \text { OR } \\
(95 \% \mathrm{CI})\end{array}$ & $\begin{array}{c}\text { p- } \\
\text { value }\end{array}$ \\
\hline \multicolumn{8}{|l|}{ Severity } \\
\hline Asymptomatic & $33(3-88)$ & $4 / 12$ & & 1 (Ref) & & 1 (Ref) & \\
\hline Mild & $47(27-68)$ & $25 / 53$ & & $10.2(0.17-613)$ & 0.27 & $8.7(0.13-594)$ & 0.31 \\
\hline Moderate & $54(39-69)$ & $38 / 70$ & 0.54 & $12.1(0.22-672)$ & 0.22 & $11.8(0.14-974)$ & 0.28 \\
\hline \multicolumn{8}{|c|}{ Loss of taste/ smell } \\
\hline No & $27(13-47)$ & $12 / 44$ & & 1 (Ref) & & 1 (Ref) & \\
\hline Yes & $60(45-74)$ & $55 / 91$ & $<0.01$ & $29.5(1.33-654)$ & $\mathbf{0 . 0 3}$ & $68.3(1.95-2389)$ & $\mathbf{0 . 0 2}$ \\
\hline \multicolumn{8}{|c|}{ (1) } \\
\hline No & $39(24-57)$ & $27 / 69$ & & 1 (Ref) & & 1 (Ref) & \\
\hline Yes & $61(43-76)$ & $40 / 66$ & 0.08 & $10.3(0.78-136)$ & 0.08 & $10.4(0.76-140)$ & 0.08 \\
\hline \multicolumn{8}{|l|}{ Cough } \\
\hline No & $27(11-53)$ & $7 / 26$ & & 1 (Ref) & & 1 (Ref) & \\
\hline Yes & $55(41-68)$ & $60 / 109$ & 0.04 & $10.0(0.54-184)$ & 0.12 & $10.2(0.51-203)$ & 0.13 \\
\hline \multicolumn{8}{|l|}{ Dyspnea } \\
\hline No & $46(29-64)$ & $31 / 68$ & & 1 (Ref) & & 1 (Ref) & \\
\hline Yes & $54(38-69)$ & $36 / 67$ & 0.50 & $1.40(0.17-12)$ & 0.76 & $0.97(0.1-9.51)$ & 0.98 \\
\hline
\end{tabular}

Abbreviations: SAR; Secondary Attack Rate, OR; Odds Ratio, CI; Confidence Interval

${ }^{a}$ Pearson chi ${ }^{2}$ test statistics was corrected with the second-order correction of Rao and Scott and converted into an F statistic

$\mathrm{b}$ adjusted for the age and sex of the primary case and household contacts, and household size (number of persons per household). 
medRxiv preprint doi: https://doi.org/10.1101/2021.08.15.21261478; this version posted September 22, 2021. The copyright holder for this preprint (which was not certified by peer review) is the author/funder, who has granted medRxiv a license to display the preprint in perpetuity.

All rights reserved. No reuse allowed without permission.

Table 5. Effect of behavioral factors and precautionary practices on secondary attack rate (SAR).

\begin{tabular}{|c|c|c|c|c|c|c|c|c|}
\hline & & $\begin{array}{l}\text { SAR\% } \\
(95 \% \mathrm{CI})\end{array}$ & $\begin{array}{l}\mathrm{PCR}^{+} / \\
\text {HH } \\
\text { contacts }\end{array}$ & $\begin{array}{l}\text { p- } \\
\text { value }^{a}\end{array}$ & $\begin{array}{l}\text { Crude OR } \\
(95 \% \text { CI })\end{array}$ & $\begin{array}{l}\text { p- } \\
\text { value }\end{array}$ & $\begin{array}{l}\text { Adjusted OR } \\
(95 \% \mathrm{CI})\end{array}$ & $\begin{array}{l}\text { p- } \\
\text { value }\end{array}$ \\
\hline \multicolumn{9}{|c|}{ Behavioral factors: contact with the primary case prior to confirmation of infection } \\
\hline \multirow{2}{*}{ Cared for } & No & $48(35-61)$ & $51 / 106$ & & 1 (Ref) & & 1 (Ref) & \\
\hline & Yes & $53(27-78)$ & $8 / 15$ & 0.70 & $1.14(0.31-2.74)$ & 0.91 & $0.54(0.04-6.79)$ & 0.63 \\
\hline \multirow{2}{*}{ Hugged } & No & $39(21-61$ & $11 / 28$ & & 1 (Ref) & & 1 (Ref) & \\
\hline & Yes & $52(37-66)$ & $48 / 93$ & 0.28 & $3.26(0.54-9.60)$ & 0.20 & $3.90(0.55-27.7)$ & 0.17 \\
\hline \multirow{2}{*}{ Kissed } & No & $44(29-60)$ & $26 / 59$ & & 1 (Ref) & & 1 (Ref) & \\
\hline & Yes & $53(36-70)$ & $33 / 62$ & 0.41 & $7.14(0.86-9.10)$ & 0.07 & $5.27(0.63-44.0)$ & 0.13 \\
\hline \multirow{2}{*}{$\begin{array}{l}\text { Shook/ } \\
\text { held hands }\end{array}$} & No & $47(30-65)$ & $16 / 34$ & & 1 (Ref) & & 1 (Ref) & \\
\hline & Yes & 49 (36- 63 & $43 / 87$ & 0.80 & $3.51(0.56-22.02$ & 0.18 & $4.30(0.52-35.5)$ & 0.18 \\
\hline \multirow{2}{*}{ Ate together } & No & $50(25-75)$ & $6 / 12$ & & 1 (Ref) & & 1 (Ref) & \\
\hline & Yes & $49(36-62)$ & $53 / 109$ & 0.91 & $1.58(0.20-2.78)$ & 0.67 & $1.72(0.19-15.1)$ & 0.63 \\
\hline \multirow{2}{*}{$\begin{array}{l}\text { Shared a } \\
\text { cup/glass/bottle }\end{array}$} & No & $49(36-62)$ & $50 / 102$ & & 1 (Ref) & & 1 (Ref) & \\
\hline & Yes & 47 (20-77) & $9 / 19$ & 0.92 & $0.85(0.10-0.25)$ & 0.88 & $0.60(0.06-5.64)$ & 0.65 \\
\hline \multirow{2}{*}{$\begin{array}{l}\text { Slept in the } \\
\text { same room }\end{array}$} & No & $43(26-61)$ & $25 / 58$ & & 1 (Ref) & & 1 (Ref) & \\
\hline & Yes & $54(39-68)$ & $34 / 63$ & 0.30 & $3.40(0.79-4.66)$ & 0.10 & $2.58(0.53-12.5)$ & 0.24 \\
\hline \multirow{2}{*}{ Shared a bed } & No & $42(27-60)$ & $25 / 59$ & & 1 (Ref) & & 1 (Ref) & \\
\hline & Yes & $55(40-69)$ & $34 / 62$ & 0.19 & $2.93(0.68-2.54)$ & 0.15 & $2.18(0.45-10.5)$ & 0.34 \\
\hline \multirow{2}{*}{ Shared a toilet } & No & $20(2-71)$ & $2 / 10$ & & 1 (Ref) & & 1 (Ref) & \\
\hline & Yes & $51(38-65)$ & $57 / 111$ & 0.10 & $117(0.5-26964)$ & 0.085 & $125(0.5-29152)$ & 0.08 \\
\hline \multicolumn{9}{|c|}{ Precautionary practices: performed by primary cases after confirmation of infection } \\
\hline \multirow{2}{*}{ Isolated $^{\mathrm{c}}$} & No & $67(40-86)$ & $33 / 22$ & & 1 (Ref) & & 1 (Ref) & \\
\hline & Yes & $42(28-57)$ & $37 / 88$ & 0.10 & $0.07(0.00-1.15)$ & 0.06 & $0.06(0.00-1.19)$ & 0.07 \\
\hline \multirow{2}{*}{$\begin{array}{l}\text { Social } \\
\text { distanced } \\
(\geq 2 \mathrm{~m})\end{array}$} & No & $59(40-76)$ & $35 / 59$ & & 1 (Ref) & & 1 (Ref) & \\
\hline & Yes & $39(23-57)$ & $24 / 62$ & 0.11 & $0.11(0.01-1.31)$ & 0.08 & $0.10(0.01-1.32)$ & 0.08 \\
\hline \multirow{2}{*}{$\begin{array}{l}\text { Used } \\
\text { face mask }\end{array}$} & No & $55(38-70)$ & $46 / 84$ & & 1 (Ref) & & 1 (Ref) & \\
\hline & Yes & $35(19-56)$ & $13 / 37$ & 0.12 & $0.13(0.01-1.62)$ & 0.11 & $0.12(0.01-1.51)$ & 0.10 \\
\hline \multirow{2}{*}{$\begin{array}{l}\text { Slept in a } \\
\text { different room }\end{array}$} & No & $67(44-85)$ & $29 / 43$ & & 1 (Ref) & & 1 (Ref) & \\
\hline & Yes & $38(25-54)$ & $30 / 78$ & 0.03 & $0.08(0.01-0.98)$ & 0.048 & $0.07(0.00-0.98)$ & 0.048 \\
\hline \multirow{2}{*}{$\begin{array}{l}\text { Used separate } \\
\text { bathroom/ toilet }\end{array}$} & No & $53(38-68)$ & $41 / 77$ & & 1 (Ref) & & 1 (Ref) & \\
\hline & Yes & $41(21-64)$ & $18 / 44$ & 0.35 & $0.30(0.03-3.00)$ & 0.31 & $0.30(0.02-3.63)$ & 0.34 \\
\hline \multirow{2}{*}{$\begin{array}{l}\text { Did not share a } \\
\text { towel/ items }{ }^{\mathrm{d}}\end{array}$} & No & $69(25-94$ & $11 / 16$ & & \multirow{2}{*}{ NA } & \multirow{2}{*}{\multicolumn{2}{|c|}{ NA }} & \\
\hline & Yes & $49(32-67)$ & $30 / 61$ & 0.34 & & & & \\
\hline \multirow{3}{*}{\multicolumn{9}{|c|}{$\begin{array}{l}\text { Abbreviations: SAR; Secondary Attack Rate, OR; Odds Ratio, CI; Confidence Interval } \\
{ }^{a} \text { Pearson } \text { chi }^{2} \text { test statistics was corrected with the second-order correction of Rao and Scott and converted into an F statistic }\end{array}$}} \\
\hline & & & & & & & & \\
\hline & & & & & \multicolumn{4}{|c|}{ b adjusted for age and sex of the primary case and household contacts, and household size (number of persons per household) } \\
\hline \multicolumn{9}{|c|}{$\begin{array}{l}\text { c defined as resided in a separate room and kept } \geq 2 \text { meters distance from the rest of the household members, did not share a } \\
\text { bedroom }\end{array}$} \\
\hline
\end{tabular}




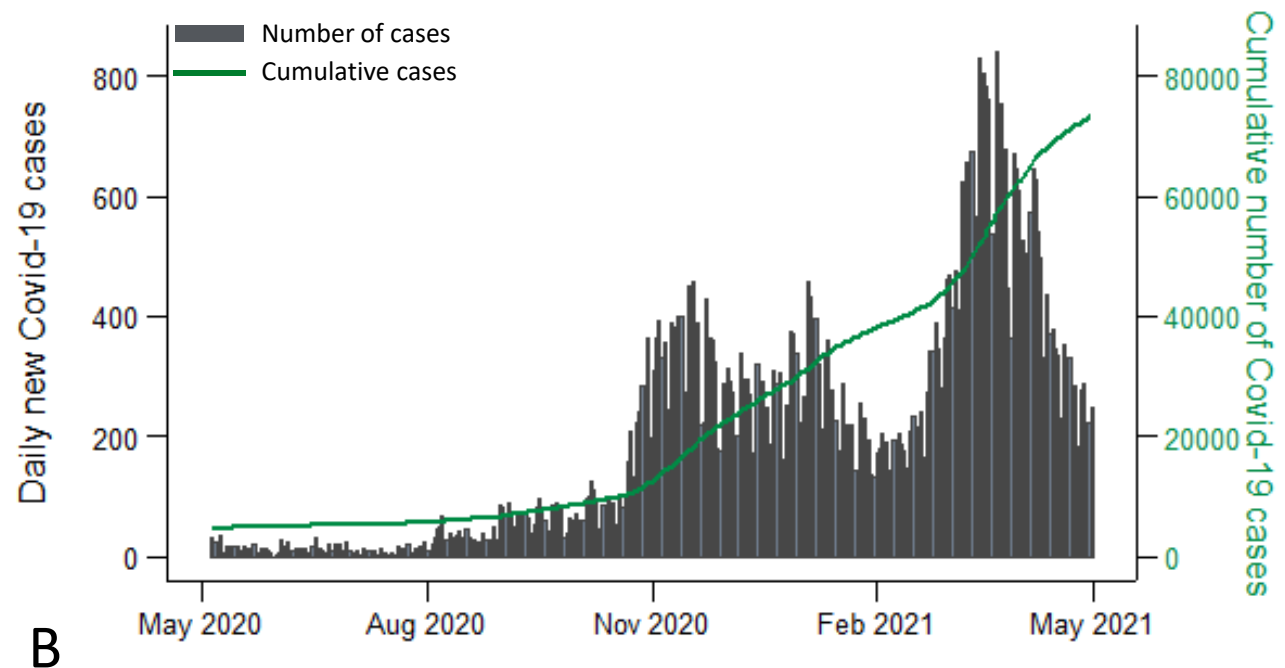

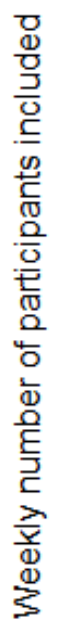

Date

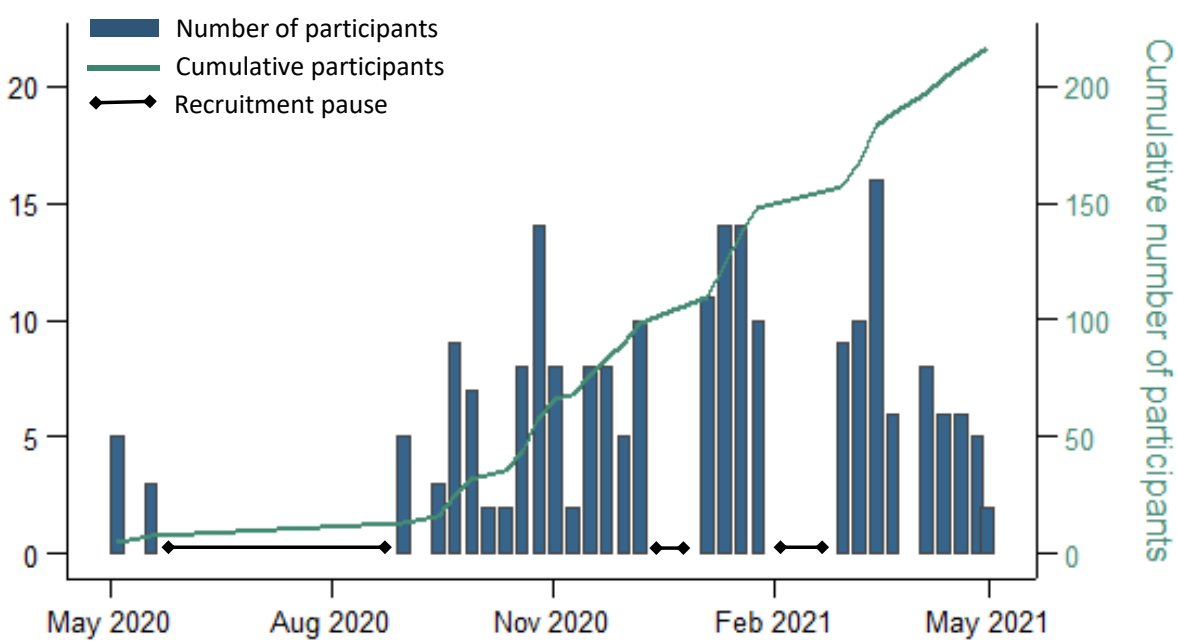

Date

Figure 1: The course of the COVID-19 pandemic in Oslo/Viken, Norway, and the number of participants included in the study, from May 12020 to April 32021.

A) The number of all reported laboratory confirmed COVID-19 cases in Oslo/Viken, Norway, during the study recruitment period. Participating households were recruited from these two counties. The daily number of cases is shown in grey, while the cumulative number of cases is shown in green. Source: Norwegian Surveillance System for Communicable Diseases (MSIS).

B) The number of included participants during the study recruitment period. The weekly number of participants included is shown in blue, while the cumulative number is shown in green. Three recruitment pauses are indicated. 


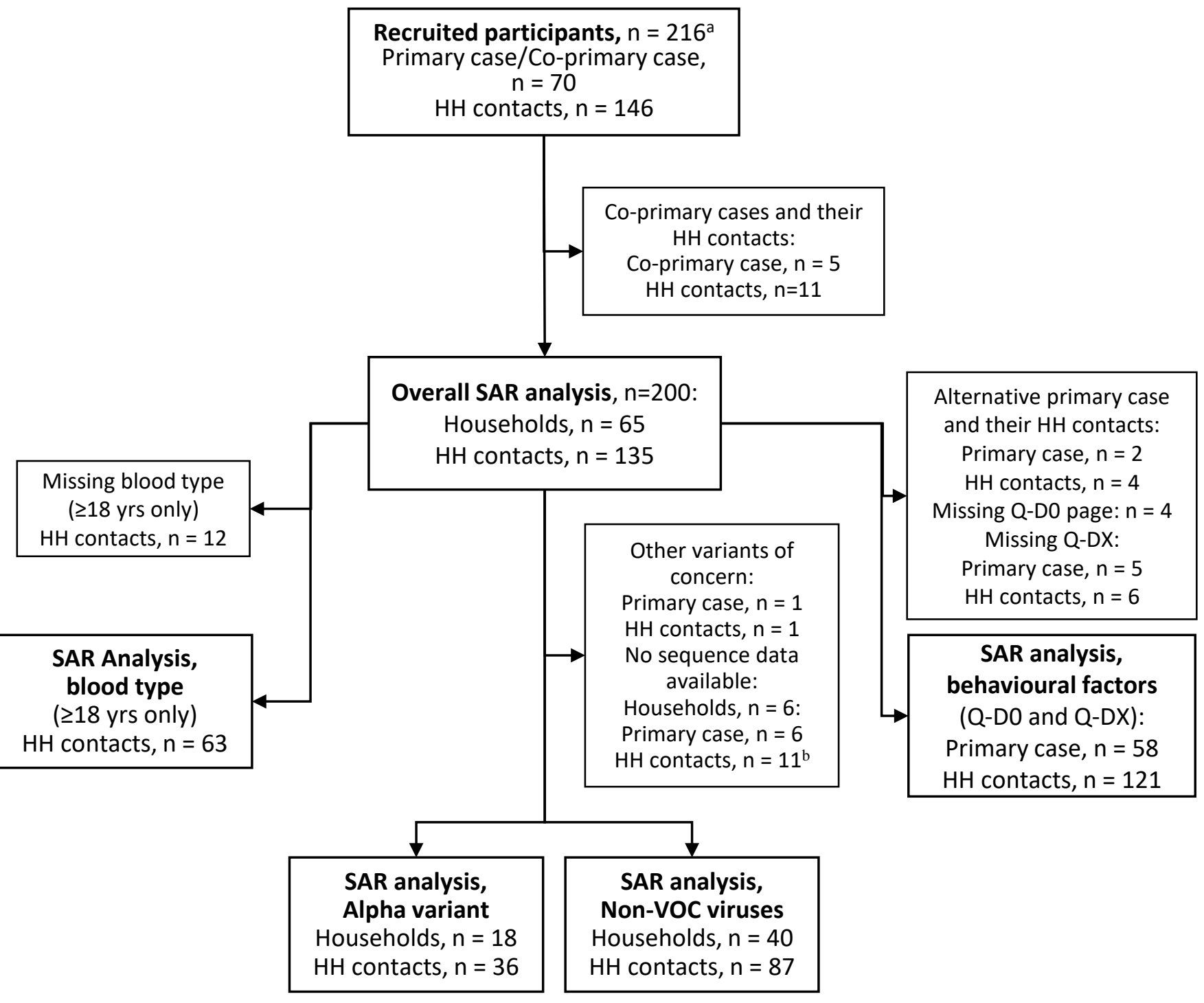

Figure 2: Flow chart of participant selection for the different analyses.

Abbreviations: HH contact, household contact; non-VOC, non-Variant of Concern

${ }^{a}$ recruited participants were tested for SARS-CoV-2 by RT-qPCR and provided information on symptom onset (Q-D0 questionnaire)

$\mathrm{b}$ includes household contacts that were SARS-CoV-2 negative 

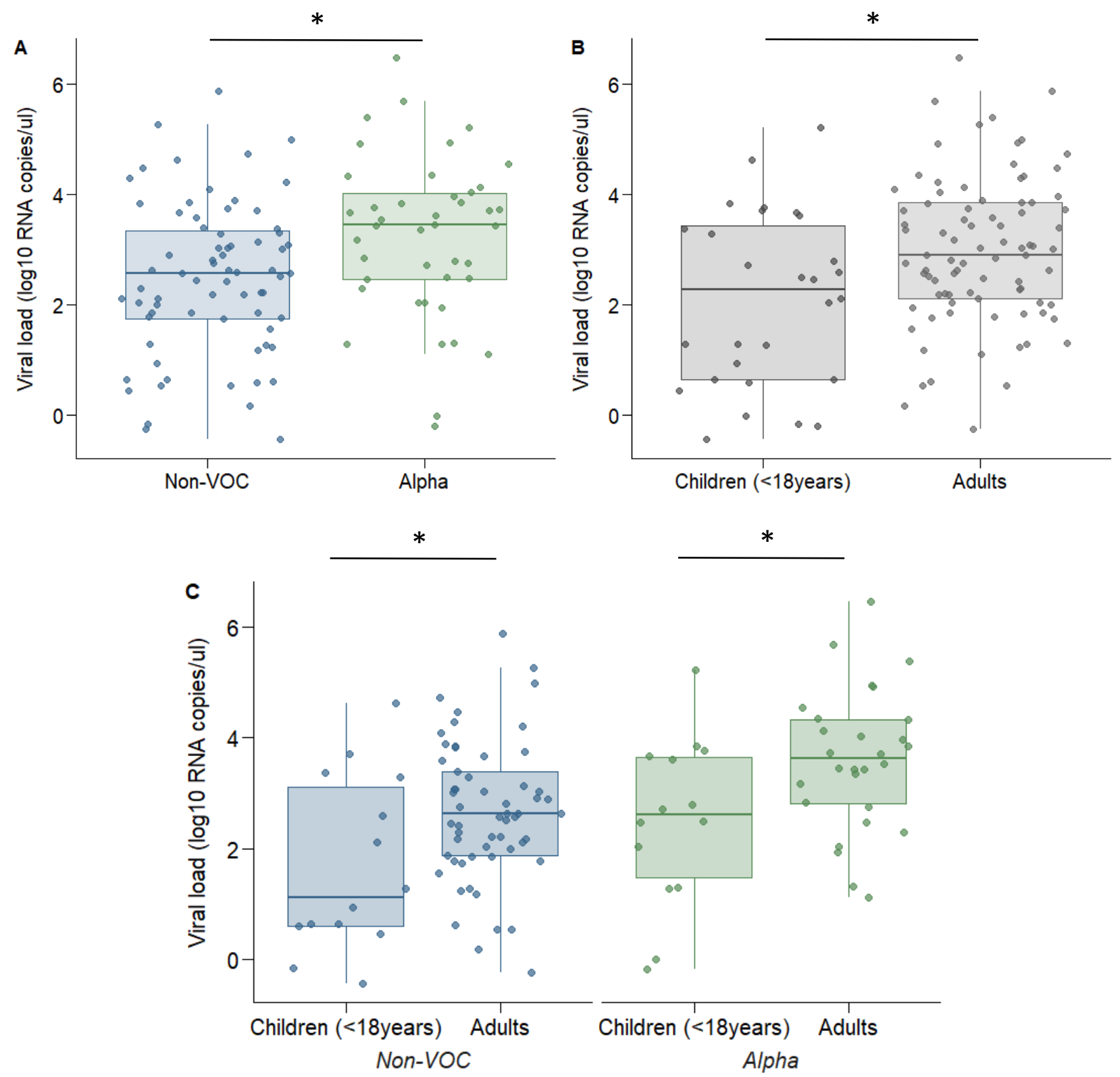

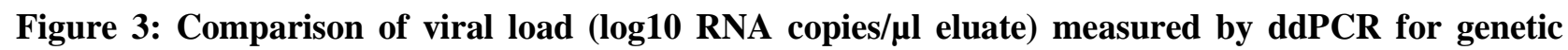
variant and age groups

Abbreviations: non-VOC, non-Variant of Concern

A) Comparison of viral load between non-VOC $(n=71)$ and Alpha viruses $(n=42)$

B) Comparison of viral load between children $(n=28)$ and adults $(n=85)$ for all genetic variants combined

C) Comparison of viral load for genetic variants and age groups: non-VOC; children $(n=14)$ versus adults $(\mathrm{n}=57)$, and Alpha variant; children $(\mathrm{n}=14)$ versus adults $(\mathrm{n}=28)$

$* \mathrm{p}<0.05$. P-values were estimated using a mixed-effects linear regression. 